\title{
Dynamic Level of SMES E-Commerce Readiness Level: An Empirical Investigation in Indonesia
}

\author{
Rochmat Aldy Purnomo ${ }^{2 *}$ J J Sarungu ${ }^{1}$, Bhimo Rizky Samudro ${ }^{1}$, Tri Mulyaningsih ${ }^{1}$, \\ Rizki Listyono Putro ${ }^{2}$
}

${ }^{1}$ Faculty of Economics and Business, Universitas Sebelas Maret Surakarta, Indonesia

${ }^{2}$ Faculty of Economics, Universitas Muhammadiyah Ponorogo, Indonesia

*Corresponding author. Email: rochmataldy93@gmail.com

\begin{abstract}
The purpose of research is to describe the profile of SMEs, evaluate and measure the level of e-commerce readiness ability of SMEs which doing in Indonesia, which starting in Ponorogo. The analytical tool used is an ecometer that serves to measure the level of ecommerce readiness capability for registered and monetize the product that are divided into three stages, basic (level 1 to level 3), medium (level 4 to level 6) and ready (Level 7 to Level 9). By using ecometer is expected to provide basic information about the mapping of potential needs and the use of appropriate e-commerce both tools, process and production in Ponorogo. The results of the evaluation and measurement showed that all samples had not passed the measurement at level 1 to level 3. In addition, no one has passed the middle level 4 to level 6, while the toplevel measurement, namely level 7 to level 9 only get a maximum score of 60 percent. This explains that SMEs still needs government intervention both in the use of appropriate intellectual property, as well as supporting indicators such as management to register the product, quality improvement in production, and human resources.
\end{abstract}

Keywords: SMES, e-commerce, readiness level

\section{INTRODUCTION}

In the current era of globalization, trends to use internetbased technology have become everyone's needs. Information and communication technology can increase inspiration for those who have a product, and can have a direct effect on business targets [1]. In Indonesia, readiness for the adoption of information and communication technology can improve business positions in global supply chains. One innovation that is highly developed, namely ecommerce. By developing e-commerce innovations that also use information and communication technology, and encompass electronic business concepts, can improve business transactions [2].

The supply and demand for goods and services can be made electronically and done online. Ecommerce applications entirely in terms of application, data transfer or trade itself [3]. Then, production of small industries, home industries and SMEs rely heavily on the availability of existing technology, of course with the ability and financial capacity in using the technology. Production must continue to run because it is a source of income for small industries, home industries and SMEs with existing technology that has not been able to penetrate markets outside the region or export, further impact is less developed so that the goal to be more prosperous to less than the maximum results. Basically, the use of technology is not solely to be with advanced technology, but using technology based frugal innovation is able to answer the situation [4].

Indonesia is one of the countries in Southeast Asia that has positive potential in the world. On one hand, the factors of population, poverty, economic growth has always been a challenge for Indonesia, in order to compete and not to lag behind other countries in the world. Therefore, the resources available in Indonesia can be used effectively by adopting technology that is adapted to the values and culture in Indonesia. In case, East Java Province is one of the big provinces in Indonesia with the number of SMEs spread evenly, and one of the representations of SMEs equity is in the Ponorogo. The number of formal and registered SMEs units in Ponorogo is 212,947 units and absorbs 196,248 workers. Governments and business organizations have made the leap to support technology and ICT in order to increase and stimulate inclusive development.

With these conditions, this study aims to improve the readiness of e-commerce in Indonesia which, to get benefits to improve performance. Knowing the e-commerce readiness level will also help Indonesia in completing the right strategy in implementing e-commerce and increasing competitiveness which is very fast changing.

There are several resolutions related to e-commerce [5]. In general, e-commerce is defined "a modern business methodology that addresses the needs of organizations, merchants and consumers to cut costs while improving the quality of goods and services and increasing the speed of service delivery." We can study the concept of e-commerce to increase economic added value by converting conventional inputs into digital inputs through a structured process. The Organization for Economic Cooperation and Development (OECD), defines as "the electronic exchange 
of information that supports and governs commercial activities including organizational management, commercial management, commercial negotiations and contracts, legal and regulatory frameworks, financial settlement arrangements and taxation" [6].

At the grassroots level, an interesting depiction is seen in the perspective of e-commerce, which in principle always uses the internet. In other words, e-commerce resolution itself can be seen from several points of view [7]. In the perspective of communication itself, it is a delivery that contains information, products and services through payment by electronic facilities. From a business perspective, planning technology to improve business transactions and workflows with automation. In a service perspective, e-commerce is a tool to measure customer satisfaction, consumer desires, cut service costs and improve shipping quality. In an online perspective, ecommerce can provide convenience in buying and selling products online.

The World Bank has a more specific definition, which "commercial transactions occurring over open networks, such as the Internet. Both business-to-business and business-to-consumer transactions are included." This paper contains the definition of e-commerce for clearer and simpler information. We can get benefit from the existence of e-commerce that is most important in the functioning of the market [8]. Producers and customers can gain access to a wider market while reducing costs and saving time. Producers and consumers can also communicate directly. With the concept of e-commerce, transaction costs that can be obtained for producers and increased access to information for consumers is a positive thing that can be accepted in a perfectly competitive market. Then, with direct communication between producers and consumers, some opportunities in the market can be reduced. On the other hand, e-commerce also introduces new things such as speed, cross-border jurisdiction, and global market renewal. This has led to support for the government, in ecommerce on the side of trade and income tax maintenance, consumer privacy protection, intellectual property protection and others.

Used the Technology Readiness Level (TRL) which has four components and measured through 31 variables [9] used four components - Optimism, Innovativeness, Discomfort and Insecurity. In this paper, we also introduce a new method, call E-Commerce Readiness Level (ECRL), which has modified from TRL itself. This model focuses on technological concepts for e-commerce adoption, without including human factors, culture and artistic value. There are other studies, related to the diffusion e-commerce model in Brazil, which are considered in e-commerce valuation [10]. The study approved the approval of the achievement of Brazil in approving e-commerce, by fulfilling the adoption requirements themselves.

\section{METHOD}

This type of research is descriptive explorative by providing a description through a series of survey activities on selected respondents, for the purpose of exploration, outlining, explanatory, namely to explain causal relationships and hypothesis testing, evaluation, prediction or predicting certain events in future, operational research and development of social indicators. The focus of this research is citizens who have a product which sell in Ponorogo Regency with a sampling model of the existing SMEs population.

From the population, samples need to be determined also surveyed. So, from a population of 2,337 family heads, the sample to be surveyed was 294 heads of families using the One Stage Cluster. While for secondary data comes from supporting documents that can be legally referred. Measuring the level of e-commerce readiness capability is carried out using an ecometer. Ecometer is a spreadsheetbased software from Microsoft Excel that collects a number of standard questions for each level and displays ECRL achieved graphically. This software is quite helpful in the ECRL measurement process.

\section{RESULTS AND DISCUSSION}

In level 1 measurements of 294 respondents all were met, this shows the lowest level of e-commerce readiness. In this level 1 measurement the indicator is that basic assumptions and laws such as physics/chemistry used in e-commerce have been determined. The study of literature (theory/ empirical-previous research) about the basic principles of ecommerce that will be developed indirectly already exists. The composition of ingredients in each business unit already exists with a hereditary tendency from its predecessor. At this level there is no need for government intervention because the pattern in this level is the need for the SMEs business unit which must be implemented if it wants to increase its production.

In ECRL measurements of business units up to level 4, it has been below 50 percent of the total sample of SMEs who do not meet the requirements. From this measurement, it can be explained that the average business unit of cattle farmers is still in the use of appropriate e-commerce based on experience in producing it, this can be seen in the field of SMEs technology.

Most of the SMEs basically have the technology used to increase their production capacity, such as the craft production process that uses used drums, as well as modified tires. In addition, food production using modified lawn mowers and modified counter. SMEs using such technology are not an appropriate technology category but fall into the category of community technology, namely the tools used are tools that are made or modified in such a way that they have. This community technology exists because of the ability and capacity of the community to find solutions to technological problems even though they are aimed at efficiency and effectiveness of production. The government's attention in increasing the production capacity of the business units of SMEs is still very much needed, when referring to the results

\section{CONCLUSION}

SMEs in Ponorogo Regency are dominated by food and craft production businesses. Business units in the field still 
Preparation Leadership In Region Of Ponorogo. Media Trend Vol. 12 No. 2 Oktober 2017 Hal. 127-142.

process for producers. The majority of business units are still using simple e-commerce technology and not sustainable. ECRL in Ponorogo showed that all samples have measurements at level 1 to level 5. In addition, no one had passed the intermediate level, level 6 to level 7, while the upper level measurement level 7 to level 9 only gets a maximum value of 60 percent. This explains that SMEs still needs more intervention from government and another SMEs in other city, which has passed the intermediate level in the use of ecommerce technology, also register the product, quality improvement in production, human resources.

\section{REFERENCES}

[1] Castells M (1998) End of Millenium. The Information Age. Economy, Society and Culture, Vol. III. Oxford: Blackwell.

[2] , X., Kuanqi, D., and Shuqin, C. (2003) Enterprise knowledge tree model and factors of KMS based on EC; Journal of Knowledge Management, 7, 1, 96-106.

[3] Meza, M. (no year): E-Commerce; accessed on 31 May 2009 from

www.geocities.com/englishforinternationaltrade/Lesson _5_e_commerce.pdf.

[4] Purnomo, Rochmat Aldy. Titin Eka Ardiana. 2017. Mapping Potential Technology Appropriate Small and Medium Enterprises as Efforts To Improve Technology
[5] Kalakota, R and Whinston, A.B. 1997. Electronic Commerce: A Manager's Guide. New Jersey: AddisonWesley Professional.

[6] Pablo Antolin, Howard Oxley and Wim Suyker. 2001. Economic Cooperation and Development (OECD). Access:

https://www.oecd.org/finland/1863374.pdf

[7] Kosiur, D. 1997. Understanding Electronic Commerce. Washington, DC. Microsoft Press.

[8] Anonim. 2010. Kajian Tingkat Kesiapan Teknologi (TRL, Technology Readiness Levels). Jakarta: Badan Pengkajian dan Penerapan Teknologi.

[9] Sankaran, S. \& Bui, T. (2003). Relationship between student characteristics and ethics: Implications for educators, Journal of Instructional Psychology, Sept, 30, 3: 240-243.

[10] Astuti, Novika Candra., Reza Ashari Nasution. 2014. Technology Readiness and E-Commerce Adoption among Entrepreneurs of SMEs in Bandung City, Indonesia. Gadjah Mada International Journal of Business. Vol 16. No.1 hal. 69-88.

[11] G. Celebic and D.I. Rendulic. 2011. "Basic Concepts of Information and Communication Technology and Book: IT desk", Zagreb: Infokatedra, center for adult education. 